\title{
The role of islamic finance in fighting poverty
}

\author{
Lynda OUENDI \\ Teacher-research \\ Mouloud Mammeri University of Tizi-Ouzou (Algeria). \\ lynda.ouendi@gmail.com \\ Pr. Abdelmadjid ounis \\ M'hammed Bougara University of Boumerdes (Algeria). \\ am_ounis@yahoo.fr
}

\begin{abstract}
The study aims to extend and further the current literature related to the inclusion of Islamic finance in the international strategies that have been established against poverty. The study shows that despite the fact that poverty is a worldwide problem, it affects more and more the feminine gender.

Besides a number of measures and strategies that might be used to alleviate and fight against poverty, like the steps taken by the World Bank, United Unions, USAID, charities and ONGs; Islamic economic and financial system should be taken into consideration and be increasingly used in poverty alleviation policies and strategies, especially in the Muslim countries.
\end{abstract}

Keywords: poverty, inequality, Millennium Development Goals, Islamic economic and financial system.

JEL Classification:D63 - F35 - G00 - I3 - P4

\section{INTRODUCTION}

Poverty is one the most worrying phenomena at the international level. It is for this purpose that since 2000, the United Nations and its 28 partners have worked actively in the world following eight main objectives to achieve by 2015 , in order to fight against poverty and inequality presented in "The Millennium Development Goals Report 2015" (UN, 2014).

The Millennium declaration provides concrete objectives and quantifiable objectives to help countries monitor their progress, and each country is encouraged to define their strategies and to develop its national plans to achieve the Millennium Development Goals (MDGs) according to its own economic and social conditions (Population Reference Bureau, 2004).

Nevertheless, in spite the MDGs, many people still suffer from the poverty problem and gender inequality phenomenon. Thus, it would be appropriate that other strategies ought to be considered and used in order to complement those developed by the UN, such as the strategies implemented by governments, NGOs and Public and Private Charities. It is also important to take into consideration the establishment of strategies against poverty and gender inequality, the cultural dimension of societies in order to respond to their needs and requirements. Thus, the Islamic economic and financial system provides several opportunities in fighting poverty and alleviation gender inequality with a framework respecting the religious beliefs of Muslim communities that many of them live in dire socio-economic conditions. For instance, according to the World Bank, MENA (which is presented as a Muslim majority region, excluding Israel) is among the poorest region in the world, $5 \%$ of its population lives under the poverty line of $\$ 1.25$ a day. 
The purpose of this paper is to comprehend poverty, give an overview of its worldwide development and highlight the main measures and strategies being used for its reduction and hopefully its eradication. In order to be able to carry out our research study, we wish to study the following problematic: "Is Islamic economic and financial system able to support the Millennium Development Goals and contribute to the reduction of poverty and gender inequality in the world?"

In order to be able to carry out our study, we used an analyticalapproach, based on a theoretical and empirical literature review, as well as, a set of studies and reports carried out by academics, scholars and worldwide organizations ( such as UNDP, UNICEF, OECD, World Bank, International Monetary Funds, no-governmental organizations). This method allowed us to analyze the different data and reports relating to fighting poverty in the world and to analyze the contribution of Islamic economic and finance system in poverty reduction.

To analyze the main question of this research, we have structured our paper into two main sections. In the first section, we have given an overview on poverty and gender inequality in the world. In the second section, we have presented some of the most important measures and strategies developed against poverty and gender inequality, mainly the MDGs, with a focus on the role of the Islamic economic and financial system.

\section{AN OVERVIEW OF POVERTY IN THE WORLD \\ 1.1. CONCEPTUAL BACKGROUND}

It is not easy to define poverty and to give a universal definition; for this, several authors have attempted to explain what poverty means. Geremek (1987)studied poverty over a span of five centuries and he noted that in each period, the approaches to poverty were different, the definitions and the solutions diverge. For Simmel (1907), poverty is a concept that does not correspond to the needs of the poor but to the needs of those who dominate society. He said: "If assistance were to be based on the interests of the poor, there would be, theoretically, no limit possible to the transfer of property to the poor, a transfer that would lead to the equality of all."

However, although there are in the approach to poverty a real consensus that considers poverty as multidimensional phenomenon, the World Bank, as whether households or individuals have enough resources or abilities today to meet their needs. There is still inequality in the distribution of income, consumption or other attributes across the population (health and nutrition, literacy, insecurity, ...) and vulnerability, defined here as the probability or risk today of being in poverty, or failing deeper into poverty, in the future.

There are different possibilities for measuring poverty, based on monetary and non-monetary approaches. Thus, the World Bank (considered as the international reference in measuring monetary poverty) measures absolute poverty by calculating the price of basket of essential goods and takes that as the poverty threshold, which is US\$ 1.25 per day (Mestrum\&Ozden, June 2012). Nonmonetary measures of poverty produce even greater variations than those of monetary poverty. As poverty is consideredmultidimensional, one should measure the multiple dimensions at stake. For this, considerable effort has been expended on calculating composite indexes of this multidimensionality, such as taken by the UNPD ${ }^{1}$, which began in 1990 with a human development

${ }^{1}$ United Nations Development Programme

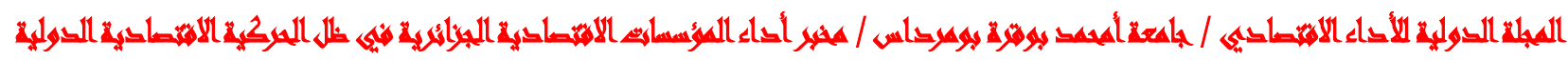
العقى الأول - ميوان 2018 
index (HDI), taking into account gross income, literacy and life expectancy (Mestrum\&Ozden, June 2012). In 1997, the UNDP calculated a "human poverty" index, leaving aside income per se but integrating into it life expectancy, literacy, malnutrition of children under five, lack of drinking water and health care and the maternal mortality level (UNDP, 1997). In its 2011 report, the UNDP offered a new measurement and a Multidimensional Poverty Index (MPI) (Mestrum\&Ozden, June 2012), which comprised indicators on education (years of schooling, school attendance), health (nutrition, child mortality) and standard of living (cooking fuel, sanitation, water, electricity, floor, assets)(Alkire et.al, 2013).

Besides being multidimensional, poverty may be more severe when it becomes chronic. Chronic poverty(Shepherd et.al, 2014)is characterized by its long duration. Chronically poor people experience deprivation over many years. They may live in poverty for their entire lives and often pass their poverty to future generations through their children. The chronically poor also tend to be severely poor living in less than US\$ 0.70 a day. The Figure 1 represents an overview of chronic poverty phenomenon.

Figure 1: Explaining chronic poverty

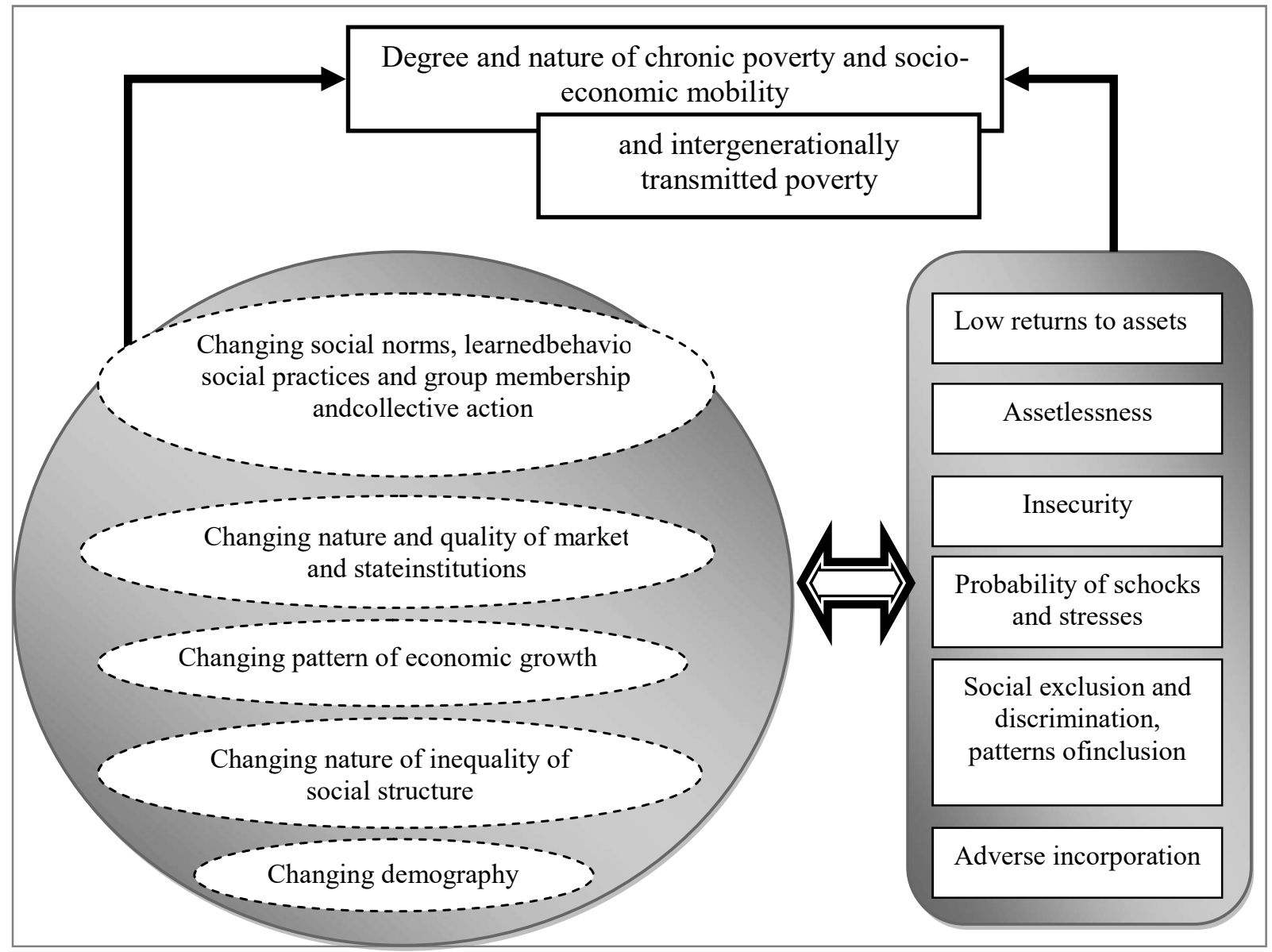

Source: Shepherd et.al (2014). The chronic poverty report 2014-2015: The road to zero extreme poverty. Overseas Development Institute. UK.P 17.

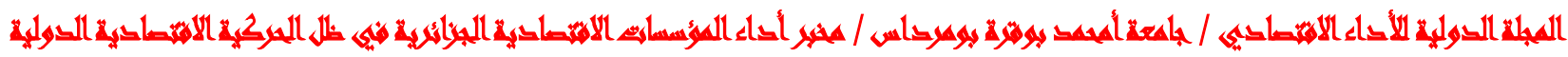
العقى الاول - ميان 2018 


\subsection{THE PREVALENCE OF POVERTY IN THE WORLD}

According to $\boldsymbol{U N}$ Report (2014): (a) about one in five persons in developing regions lives on less than $\$ 1.25$ per day; $(b)$ vulnerable employment accounted for $56 \%$ of all employment in developing regions, compared to $10 \%$ in developed regions; $(c)$ about 173 million fewer people worldwide suffered from chronic hunger in 2001-2013 than in 1990-1992; $(d)$ one in four children under age five in the world has inadequate height for his or her age; $(e)$ every day in 2013, 32,000 people had abandon their homes to seek protection due conflict.

Based on the International Monetary Fund's data, the Global Finance Magazine publishes each year a rank of countries according to the average annual income per person. The rank includes the parity of purchasing power, which takes into account the cost of living and inflation in each country. The results of 2015, presented in the Figure 2, show that the majority poorest countries in the world are African, and this could be explained by the violence, political mismanagement, corruption, a heavy reliance on donor financing, illiteracy and gender inequality.

Figure 2: The 20 world's poorest countries in 2015

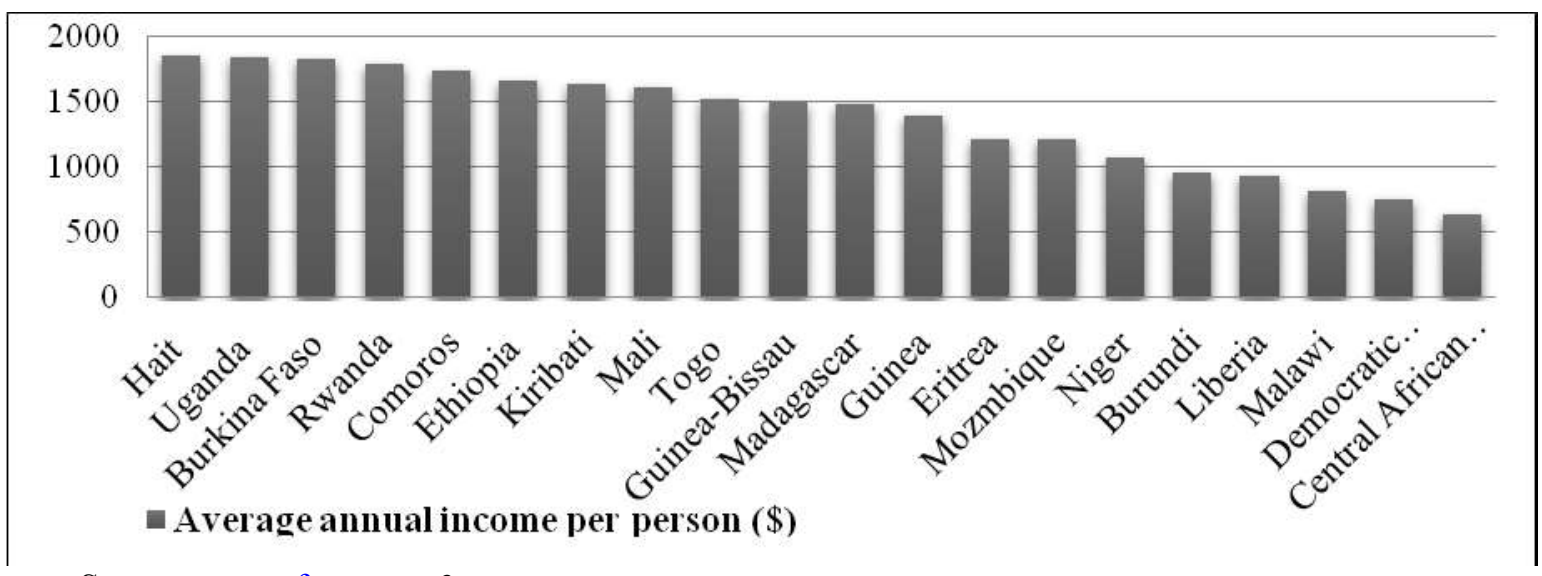

Source: $\underline{w w w . g f m a g . c o m} \& \underline{w w w . m s n . c o m}$

Hunger is one of the major aspects of poverty. Effectively, a total of 842 million people, or about one in eight people in the world, were estimated to be suffering from chronic hunger in 2011-2013. The vast majority of those people ( 827 million) resided in developing regions; and this despite the different strategies developed for poverty reduction in these regions: the rate decreased from $23.6 \%$ in 1990-1992 to $14.3 \%$ in 2011-2013 (United Nations, 2014), as it's represented by the Figure 3. One of the serious consequences of hunger is the underweight of children: an estimated 99 million children under age five in the world were underweight, in 2012, representing $15 \%$ or approximately one in seven of all children under five. For example in 2012, the proportion was $30 \%$ in Southern Asia; 21\% in Sub-Saharan Africa and 19\% in Oceania (United Nations, 2014).

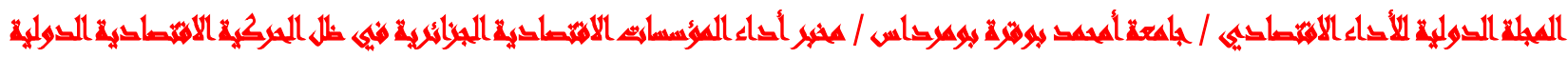
العقى الاول - ميان 2018 
Figure 3: Proportion of undernourished people in developing regions, 1990-2013 (in \%)

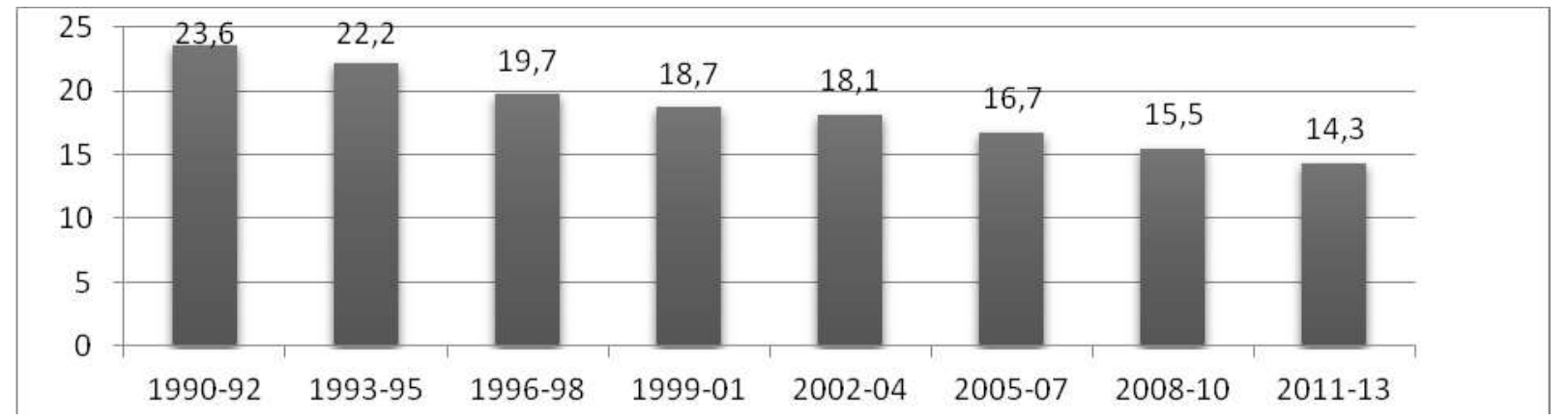

Source: United Nations (2014). The millennium development goals report. New York. USA. P 12.

Poverty is not limited only to the developing countries, but it is also presented in developed countries. For instance, in a decade, the number of poor in the United States increased by more than 15 million, from 31.6 million in 2000 to 46.2 million in 2010. This significant increase was highlighted as a result of the economic and financial crisis between 2007 and 2010. The number of poor increased by almost 10 million during the 2007-2010 period. The increase of the poverty rate has accelerated in recent years: it was around $11.3 \%$ in 2000 and $12.5 \%$ in 2007 , against $15.1 \%$ in 2010 and 14.8\% in 2014 (with a slight decrease)). (De Navas Walt et.al, 2011; 2015) From 2009 to 2010 , the poverty rate for children under age of 18 increased from $20 \%$ to $22 \%$, while the number of children under age 18 in poverty increased to 16.4 million from 15.5 million. Children accounted for $35.5 \%$ of people in poverty. In 2014, the poverty rate for children under age 18 was $21.1 \%$ (De Navas et.al, 2015). In 2014, $13.4 \%$ of males and 16,1\% of females were in poverty; gender differences in poverty rates were more pronounced for those aged 65 and older $(12,1 \%$ form women against 7.4\% form men). (De Navas et.al, 2015)

In 2014, 122 million people were at risk of poverty or social exclusion in the European Union-28 (24.24\% of the population) and more than a third of population was concerned in three member states: Romania (40.2\%), Bulgaria (40.1\%) and Greece (36\%). The rate has grown from 2008 to 2014 in 14 member states, with a highest increases being recorded in Greece (from $28.1 \%$ to $36 \%$ ). In the same year, children were at greater risk of poverty with a rate of $27.8 \%$ in the EU-28. (Lecerf, 2016)

\subsection{FEMINIZATION OF POVERTY}

The concept of "feminization of poverty" can mean either one or a combination of the following: (a) women compared to men have a higher incidence of poverty; $(b)$ women's poverty is more severe than men's; $(c)$ over time, the incidence of poverty among women is increasing compared to men. (Cagatay, 1998). This phenomenon has developed since women have been subjected to discrimination in the labor market, credit and variety of other markets. In some societies, widows, divorced or abandoned women may be subject to social exclusion, isolation and harassment, making it very difficult for them to maintain a livelihood for themselves or their children.(Cagatay, 1998).

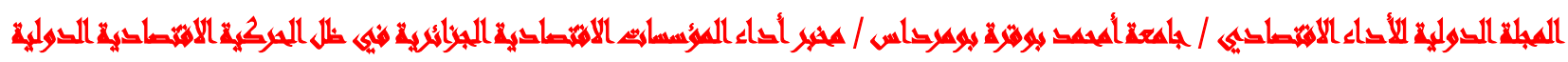
العقد الإول - موان 2018 
The feminization of poverty was first highlighted in the 1970s. Unfortunately, it was not highlighted enough until the mid-1990s. A critical catalyst was the Fourth UN Conference on Women in 1995 at which it was asserted that $70 \%$ of the world's poor were female. (Chant, 2008) Indeed, women represent disproportionate percentages of the world's poor, especially in developing countries, and according to National Women's Law Center, more than one in seven women, nearly 17,8 million, lived in poverty in 2012 ; and about $44 \%$ lived in extreme poverty ${ }^{1}$. In 2016 , half a billion women still cannot read, 62 million girls are denied the right to education and 155 countries still have laws that differentiate between men and women. (Lorde, 2016)

Women experiencing extreme poverty can be more complex and multiphase than men. In many cases, they start from more marginalized, less powerful positions than men and any additional burdens exacerbate further these differences ${ }^{2}$. Access to work is still a great challenge for women in many countries, and very often, they are entitled to vulnerable employment. Effectively, according to the 2014 United Nations report, vulnerable employment rates continued to be higher for women than for men. In developing regions, $60 \%$ of women were in vulnerable employment in 2013 , compared to $54 \%$ of men. The largest gaps were found in Northern Africa, Sub-Saharan Africa, Western Asia and Oceania. The gender gap has closed in Latin America and the Caribbean in recent year and was very small as shown in Figure 4. Around the world, women do 2/3 of work hours and produce more than half the food, but they earn only $10 \%$ of total income, own less than $2 \%$ of land, and receive less than $5 \%$ of bank loans ${ }^{3}$.

Figure 4: Proportion of down-account and contributing family workers in total employment women and men, in 2013

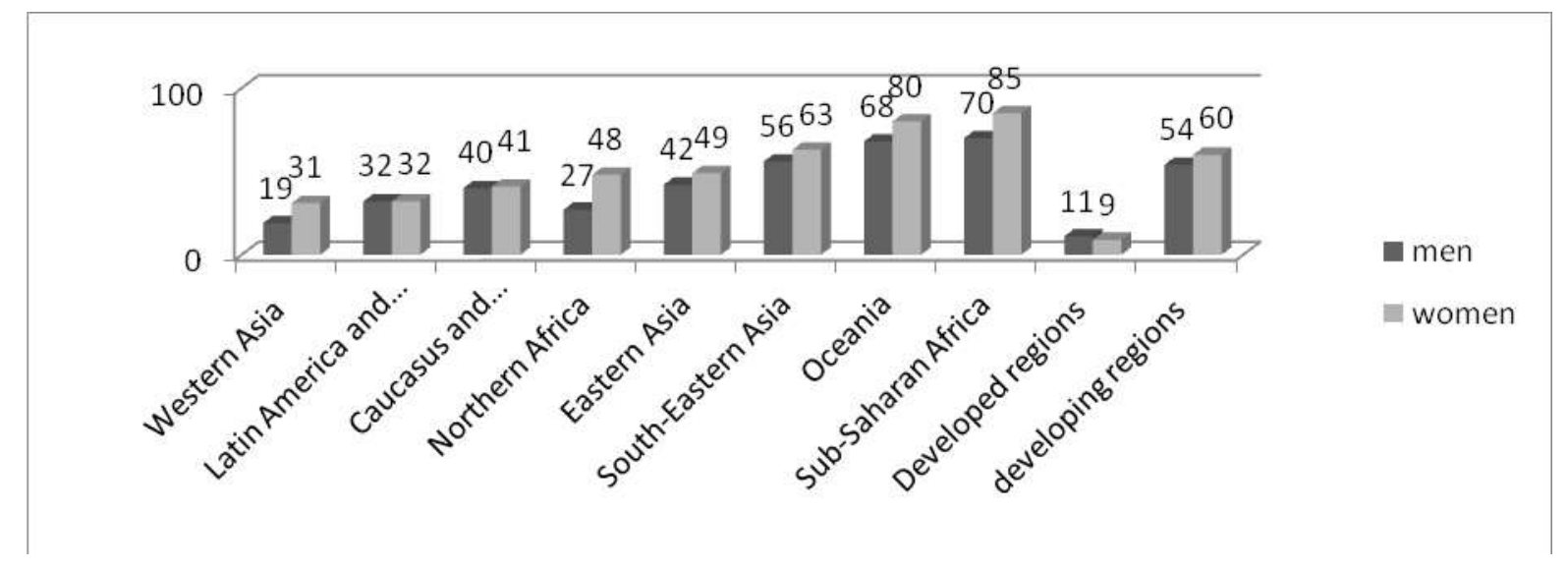

Source: United Nations (2014). The millennium development goals report. New York. USA. P11.

Several studies carried out by the UNDP, UNESCO, UN Women, UNAIDS, ... show that rural women live in poverty more than urban women, and that due to poor rural infrastructure and services as well as culturally assigned roles that severely limit women's participation in socioeconomic activities and employment opportunities ${ }^{4}$. As an important source of livelihoods for the poorest, agriculture is still a mean to eradicate extreme poverty, especially for rural women. Thus,

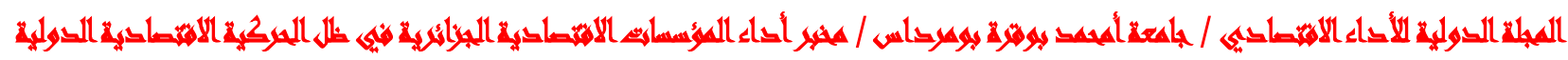
العقى الأول - ميوان 2018 
almost $70 \%$ of employed women in South-Asia and more than $60 \%$ of employed in Sub-Saharan Africa worked in agriculture in 2010; but generally for free (in family land), part time, or underpaid. (FAO, 2011)

Another aspect of women's poverty is determined through the lack of education, and gender differences in education are significant widespread. Indeed, in a recent report byUNESCO indicates that 100 million young women in poor countries are illiterate ${ }^{5}$. Sub-Saharan Africa, Oceania, Western Asia and Northern Africa still face continuing disadvantages for girls, although these regions have made substantial progress over the past two decades. The most significant progress in this group was observed in Northern Africa and a lower progress was in Sub-Saharan Africa. The greatest improvement was observed in Benin, Burkina Faso, Chad, Guinea, Mauritania, Senegal and Sierra Leone, where additional 30 to 40 more girls were enrolled in primary school for every 100 boys. (United Nations, 2014)

\subsection{THE ROLE OF GOVERNMENTS AND WORLDWIDE ORGANIZATIONS IN FIGHT AGAINST POVERTY}

Governments play a very important role in the development of strategies and policies against poverty, in national, regional and/or international environment; and generally, they work in collaboration with international organizations, NGOs and/or charities. One of the best models of government strategies is represented by USAID. In1961, the President John. F. Kennedy created the "United States Agency for International Development (USAID)", which has since continued to develop efficient strategies and allowing the agency to achieve its goals in over 100 countries, including: protect human rights, advance food security and agriculture, further education, fight against gender inequality, defend female empowerment, etc.

USAID is convening internal and outside experts to identify and understand the most effective, timely and scalable solutions to help end extreme poverty by 2030.In order to achieve the above goals, the US government has built a global partnership that would leverage efficiently the resources (USAID, 2013):

- With African governments, corporations, and the G8 in "The new Alliance for Food Security and Nutrition" to help lift 20 million people in Sub-Saharan Africa of poverty during the 2013- 2022 period.

- With the UN Global Education First Initiative in "Room to Learn", to increase equitable access to education in crisis and conflict environments for 15 million learners by 2015.

- With African governments and other U.S agencies in "Power Africa", to increase clean electricity generation capacity by more than $10.000 \mathrm{MW}$, and to expand access to electricity by at least 20 million new households and commercial entities.

- With other bilateral donors, the World Bank, the Gates Foundation, and others to launch five "Grand Challenges for Development" and "Global Development Innovation Ventures", to source proven scalable solutions to intractable development challenges.

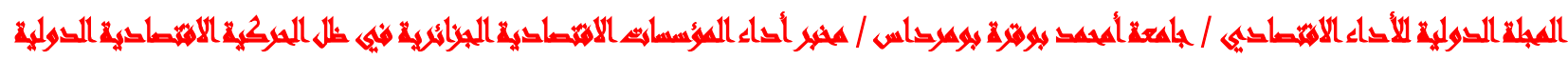
العقى الأول - ميوان 2018 
One of the key groups of actors in poverty reduction is the United Nations and its 28 partners (such as all regional Economic Commissions, International Monetary Fund; the World Bank; United Nations Development Program, World Health Organization, etc). They operate very actively worldwide and they highlighted the main goals to achieve by 2015 in order to fight against poverty, in a report known as "The Millennium Development Goals (MDG) 2015". The UN is working with governments, civil society and partners to build on the plan generated by the MDGs and pursue an ambitious agenda for the post-2015 . The MDG 2015 is composed of eight goals, namely: eradicate extreme poverty and hunger; achieve universal primary education; promote gender equality and empower women; reduce child mortality; improve maternal health; combat HIV/AIDS, malaria and other diseases; ensure environmental sustainability; develop a global partnership for development.(United Nations, 2014)

Other important contributors in poverty alleviation, such as, Non-Governmental Organizations (NGOs) and charities. They have over time, purportedly created alternative models of social change, increased inclusion of the poor and empowered communities(Nalara. R.B, 2009). Several NGOs and charities intervene around the world in order to contribute in poverty reduction and eradication, such as the Bill \& Melinda Gates Foundation, the World Fair Trade Day, the Oxfam International, the ONE, and the USAID. Many of the NGOs have developed specific specialization in enhancing women's rights and fighting gender inequality, such as the case of Madre, Women's World, Equality Now, Women Aid International, and UN Women Watch.

\section{POVERTY ALLEVIATION POLICY IN ISLAMIC ECONOMIC AND FINANCIAL SYSTEM}

In order to fight against poverty and inequality, it's necessary to seek opportunities offered by Islamic economic and finance system. The Islamic approach involves a holistic approach including a set of anti-poverty measures (Hassan, 2010): (a) increasing income level with pro-poor programs, (b) achieving an equitable distribution of income; (c) providing equal opportunities for all social segments. To achieve these goals, Islamic economic and finance system presents a number of principles (e.g: prohibition of interest, encourage profit and loss sharing), instruments and institutions that may be involved in several sectors (distribution of donations, job creation, financing industry, agriculture and infrastructures; etc.).

\subsection{THE ROLE OF ZAKAT}

Muslim countries have a very strong institution-zakat and waqf, which can contribute to poverty reduction. Some conceptual and empirical research studies advocated the integration of zakat and waqf in the poverty reduction strategy of poor countries. Among them, the study of Ahmed (2008), who highlighted two conditions under which the role of zakat in alleviating poverty would be more effective: first, zakat has to be complimented by robust macroeconomic policies that enhance also redistribute income to eliminate poverty. Second, while more zakat has to be collected and disbursed, the impact on poverty will only be significant when a larger percentage of zakat proceeds are used for productive purposes (Shirazi, 2014). Zakat and waqf can contribute to the macrocontext to the human capital improvement and to the design of specific programmes for the poor and the more vulnerable. The latter programmes may include, providing education, health facilities, and social services to improve the welfare of the poor (Ahmed, 2004).

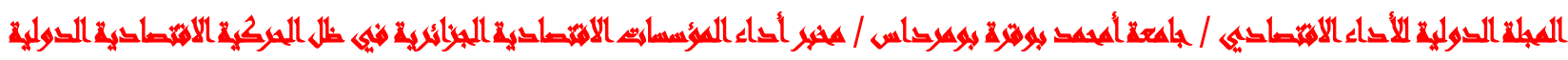

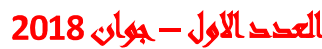


Every year, US\$ 200 billion to US\$ 1 trillion of zakat global financial value is spent in charitable acts in Muslim World. For example, in Saudi Arabia, total zakat collected has increased every year since 2010. It reached a high of US\$ 3.7 billion by mid- year 2013 and gave US\$ 5.7 billion in official development assistance in the same year, of which US\$ 109 million in international assistance. The Islamic Relief Worldwide is another example that actives in using zakat to fight against poverty in the world. It raised between US\$ 30 million and US\$ 32 million in zakat in 2013, with top donor countries were the US (US\$ 15 million, 49\% of total), the UK (US\$ 8.2 million, 27\%) and Canada (US\$ 2.7 million, 9\%). Another major participant in this field, the Zakat Foundation of America, which received, in 2013, US\$ 7.6 million in contribution and US\$ 2.1 million in in-kind donations of the total expenditure, 57\% (US\$ 4,5 million) was spent on emergency relief. This included projects in the Philippines, Pakistan, Bangladesh, Syria, Mali and within US. (Stirk, 2015).

\section{Figure 5: Zakat and sadaqah expenditure by programme area, Zakat Foundation of America, 2013}

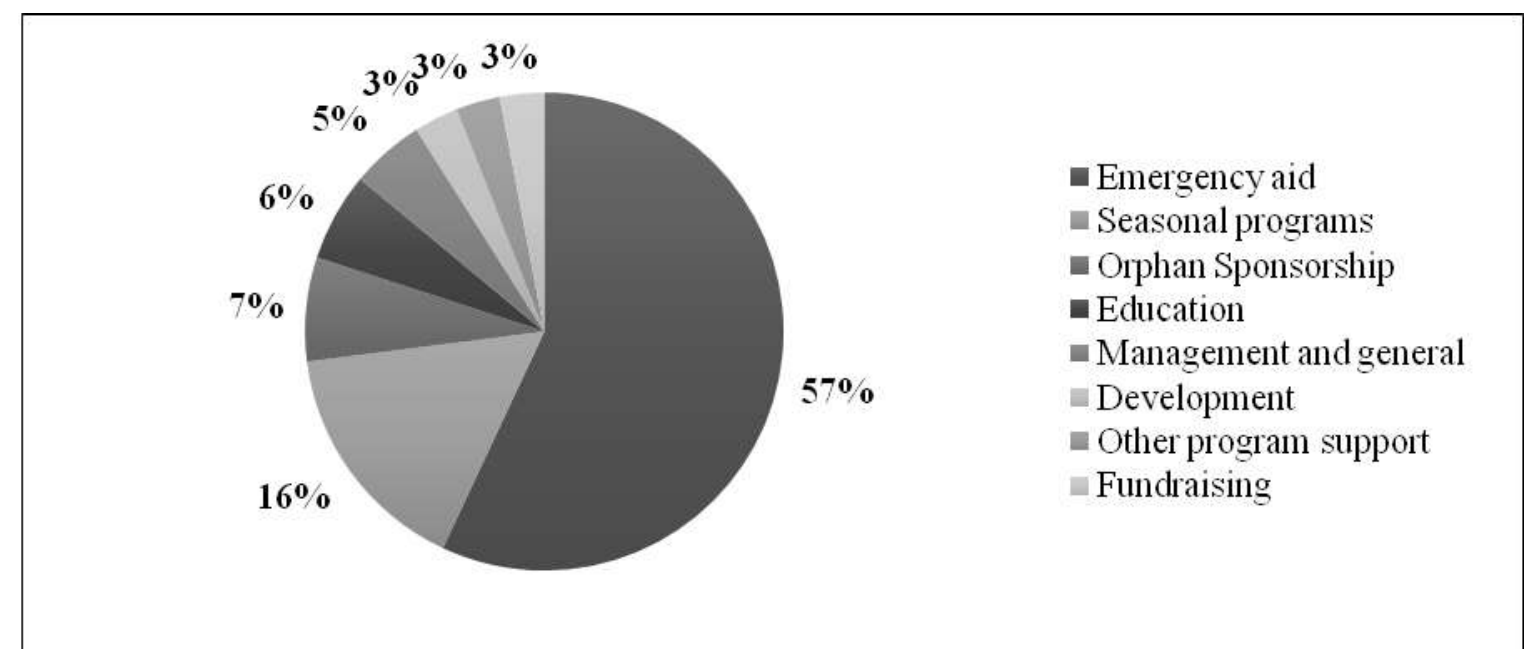

Source:Stirk Chloe (March 2015). An act of faith: Humanitarian financing and zakat. Global Humanitarian Assistance. UK. P5.

Thus, besides the distribution of zakat in the traditional way by providing cash payments to recipients, zakat can be used in the creation of investment companies, whose shareholders will be the beneficiaries of zakat, and this through the use of several Islamic financial instruments of project financing such as musharaka, mudaraba, ijara, murabaha, mougharasa and qardhassan . Effectively, zakat is mostly distributed using qardhassan mechanism by non-profit microfinance programs. The main objective of this scheme are to help the poor and establish a better relationship between the poor and the rich as well as encourage wealth transfer, increase money supply and reduce poverty by providing financial facilities for the poor in order to enhance human capital, to create jobs and business ventures. (Clarke, n.d)

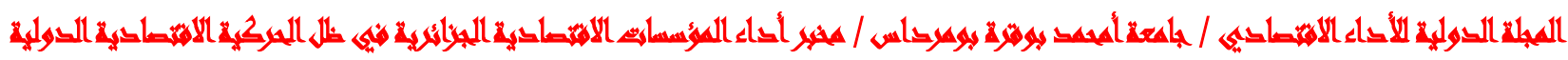
العقى الإل - يمان 2018 
For example, Algeria represents one of the countries which use zakat in financing projects through qardhassan in order to contribute in poverty reduction ${ }^{\mathbf{8}}$. Indeed, since the creation of the "Algeria zakat funds" in 2003, it has among its function the orientation of $37.5 \%$ of these funds to finance investment through qard Hassan. The qard Hassan contribution to young and needy entrepreneurs could reach the amount of 500,000 Algerian dinars ${ }^{9}$. According to the Ministry of Religious Affairs and Awqaf, 6,945 young and needy entrepreneurs (men and women) benefited from the zakat funds scheme between 2003 and 2012. The Table 1 below illustrates the evolution of qurdhassan granted by the Algerian Zakat funds during the 2003-2012 period (available period). It shows that $31.34 \%$ applicants benefited from scheme.

Table 1: The contribution of Algeria zakat funds in the granting of qard Hassan during the 2003-2012 period

\begin{tabular}{|l|r|r|r|r|r|r|r|r|r|r|r|}
\hline Year & $\mathbf{2 0 0 3}$ & $\mathbf{2 0 0 4}$ & $\mathbf{2 0 0 5}$ & $\mathbf{2 0 0 6}$ & $\mathbf{2 0 0 7}$ & $\mathbf{2 0 0 8}$ & $\mathbf{2 0 0 9}$ & $\mathbf{2 0 1 0}$ & $\mathbf{2 0 1 1}$ & $\mathbf{2 0 1 2}$ & Total \\
\hline Applicants & 7 & 1,193 & 1,789 & 2,167 & 1,855 & 1,951 & 2,073 & 2,602 & 3,447 & 5,077 & 22,158 \\
\hline Recipients & 7 & 186 & 516 & 731 & 814 & 654 & 716 & 858 & 1,125 & 1,338 & 6,945 \\
\hline
\end{tabular}

Source: Adapted from Data compilation from internal reports (2003-2013); Ministry of Religious Affairs and Waqf; Algeria.

\subsection{THE ROLE OF WAQF AND ISLAMIC CHARITIES}

If in the past, the waqfinstitution was funded by the use of limited resources such as: revenues generated by the heritage itself, the contribution of the income beneficiaries of waqf, the contribution of the government and collecting donations ${ }^{10}$. Nowdays, the waqf institution is viewed as charitable organization, a trust, a foundation, and it can use Islamic finance in order to meet its financing needs, through Islamic financial instruments (murabaha, musharaka, ijara, mougharasa, ...) for commodities and production equipment financing, and the use of agricultural land and lease of waqf property. Also, by using the Islamic financial markets, through the issuance of sukuk and stock exchange listing allowing the waqf institution to obtain funds and hence increase opportunities to contribute to fight against poverty(Ben Azouz, 2004).

The adoption of Islamic finance by the waqf institutions allows the creation of a numerous projects. Waqf is now considered to be an important element of socio-economic development. Indeed, the waqf provides funding for investment projectsand hencecontributing to job creation and improving the production of goods and services, financing of public institutions and infrastructures (schools, hospitals, cultural centers ...) and funding of scientific research and scholarships ${ }^{11}$.

One of the international Islamic charity, the "Islamic Relief Worldwide (IRW)", which was created in 1984 in Birmingham (United Kingdom), it comprises a network of independent NGOs in Belgium, France, Germany, Netherlands, Sweden, Switzerland, United Kingdom, the United States of America and Mauritius; and operates in over 40 countries. The IRW main objectives are to help poor to access basic services, including education, water, sanitation and healthcare ${ }^{\mathbf{1 2}}$.

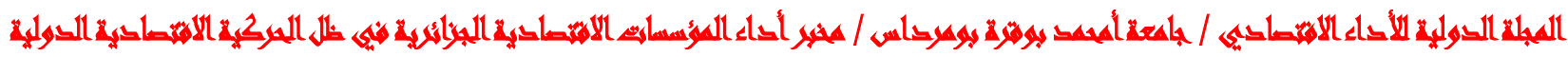

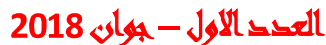


Several strategies and programmes against poverty have been developed by the IRW, and have achieved outstanding results in several countries, such as the case during 2011-2012 when the results were observed in vulnerable communities of 29 countries. Thus, in 2012, it delivered 54 relief projects in Syria and neighboring countries, providing essential medical supplies and 30 ambulances, as well as shelter, food, clothing and other vital items. In Somalia and Kenya, it delivered innovative integrated programmes which gave almost 160,000 people improved access to water and sanitation; and 58 tube wells were built in Kabul, which allowed over 155,000 people to use the wells. It rehabilitated 122 villages in flood-hit in Pakistan. In same year, across 29 countries, over 2.8 million of the world's poorest people benefited from Qurbani meat at Eid al-Adha, and over 100,000 food parcels were distributed in $£ 3$ million Ramadan programme. Also, it developed an innovation programme for almost 1,500 orphans in four cities across Albania and helped 110 women in Palestine to receive training. (Islamic Relief Worldwide, 2012)

\subsection{The role of Islamic Development Bank}

Islamic Development Bank (IDB) is an important international Islamic institution that contributes in the fight against poverty in different member countries. The Bank's financing, through Islamic finance instruments, has given priority to meeting basic needs of poor, including employment opportunities, especially to the rural poor; improving basic rural and pre-urban infrastructure such as the supply of drinking water and electric power; and expending education and health facilities. It has established a series of development programs for women to promote their participation in the process of economic and human development and poverty reduction. The bank has concentrated on five key sectors that form the core of poverty reduction efforts, namely: education, health, rural and agricultural development, water supply and sanitation, transport and energy. ${ }^{13}$

The IDB initiated numerous development initiatives and programs in recognition of the socioeconomic challenges facing member countries in Africa, and especially the Sub-Saharan Africa. One of these initiatives has been tagged as "Special Program for the Development of Africa (SPDA)" in 2008, and five critical sectors have been identified for its operational activities. They are: $(a)$ productivity growth in agriculture to achieve food security; $(b)$ education projects to generate skilled workforce; $(c)$ health focusing on the fight against major communicable diseases; $(d)$ water and sanitation projects improve quality of life; and (e) power generation and distribution projects. (Islamic Development Bank, 2008)

In 2012, cumulative approvals of interventions in the education sector were around 2.8 billion US dollars covering 481 operations (basic, secondary, tertiary and TVET $^{2}$ ). To reduce poverty particularly among women and youth in rural areas through the provision of functional literacy skills and access to micro-finance, IDB has put aside an envelope of US\$500 million in order to meet their engagements through member countries. The IDB approved US\$250 million to help affected member countries in the Arab region combat chronic youth unemployment. At the same year, IDB's cumulative financing for the health sector reached US\$2 billion for 297 operations. Cumulatively, approvals for agriculture amounted to US $\$ 4$ billion, bearing testimony to IDB's

\footnotetext{
${ }^{2}$ TVET: Technical Vocational Education and Training
}

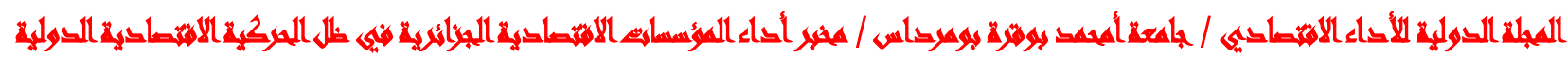
العقى الأول - ميوان 2018 
commitment to fostering food security and developing agriculture in its member countries. Infrastructure is one of the priority areas through which IDB supports its member countries, and in 2012, IDB's active infrastructure portfolio comprised 194 operations for US\$12.6 billion, of which 36\% has already been disbursed. (Islamic Development Bank, 2013)

\subsection{THE ROLE OF ISLAMIC MICRO-FINANCE AND QARDHASSAN}

While the exclusion of the poor from the financial system is a major factor contributing to their inability to participate in the development process, in a typical developing economy, microfinance is considered as a powerful poverty alleviation tool as implies provision of financial services to poor and low-income people. Access to services such as, credit, venture capital, savings, insurance, remittance is supposed to help the poor to increase household income and economic security, build assets and reduce vulnerabilities ${ }^{\mathbf{1 4}}$. Promoters of microfinance programs argue that increasing women's access to such funding increases their financial capacity, improves their self-esteem and their status, both within the household and within their community. It is further argued that the increase in women's income improves health, nutritional status and education of other household members, particularly children (Ajaz, 2008). In this regard,Chapra (1992) believes that the socioeconomic goals set by the Shari'awill be achieved more effectively by promoting the development of micro-enterprises (RiwajantiNur Indah, 2014).

The Islamic microfinance can be represented by micro-saving (based on the contract of mudaraba, musharaka and takaful), the micro-credit (based on qard Hassan, murabaha and salam), micro-lease (based on ijara) and micro-takaful (also known as "Islamic micro-insurance", based on mutual guarantee against possible risks of borrowers) (Ben Abdelkader\& Ben Salem, 2013). The use of Islamic microfinance in the fight against poverty has increased in several countries (such as Indonesia, Pakistan, Bangladesh and MENA countries), where several institutions and organizations offer financing services of micro-projects, based on Shari'a. Among them: BaitulMaalwatTamwil in Indonesia(UN Development Programme, 2012), USAID Tijara Project in Iraq (USAID Iraq, 2013)Zakat Funds in Algeria ${ }^{\mathbf{1 5}}$,Sanadiq project at Jabal al-Hoss in Syria; Mu'assasatBayt Al-Mal in Lebanon; and Hodeidah Microfinance Programme in Yemen (Pakdeld Monroy, 2010). The table 2 gives an overview of the Islamic micro-finance contribution in the poverty reduction in MENA region in 2010.

The experience of qardhassan in the creation of micro-projects has achieved remarkable success in many countries. An activity managed by Islamic banks, such as in United Arab Emirates or by foundations and associations, such as the case of Al Qard Al-Hassan Association in Lebanon, created in 1982. Table 2 presents the number and value of loans distributed between 1983 and 2014. We can observe a steady a sustainable increase in the number of loans as well as in the value of loans.

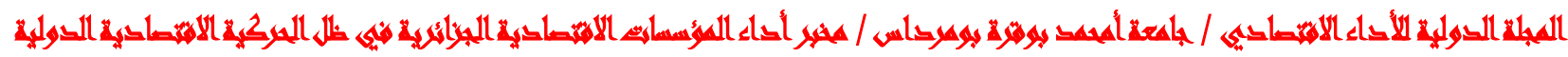

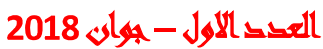


The role of islamic finance in fighting poverty

Lynda OUENDI, Pr. Abdelmadjid ounis

Table2: Al Qard Al-Hassan Association loans between 1983 and 2014

\begin{tabular}{|l|r|r|r|}
\hline Year & Number of loan & Value of loan \$ & Average loan \\
\hline $1983-2000$ & 40.464 & 25.872 .398 & 639 \\
\hline 2001 & 8.761 & 6.206 .822 & 708 \\
\hline 2002 & 12.135 & 8.918 .014 & 735 \\
\hline 2003 & 16.233 & 12.150 .289 & 748 \\
\hline 2004 & 21.165 & 16.264 .114 & 768 \\
\hline 2005 & 26.142 & 22.368 .862 & 856 \\
\hline 2006 & 30.130 & 24.858 .048 & 825 \\
\hline 2007 & 49.818 & 76.518 .174 & 1.536 \\
\hline 2008 & 60.262 & 89.430 .121 & 1.484 \\
\hline 2009 & 72.463 & 117.300 .329 & 1.619 \\
\hline 2010 & 75.476 & 132.865 .581 & 1.760 \\
\hline 2011 & 87.596 & 163.388 .452 & 1.865 \\
\hline 2012 & 100.346 & 208.435 .691 & 2.077 \\
\hline 2013 & 110.677 & 245.132 .103 & 2.215 \\
\hline 2014 & 123.696 & 276.532 .702 & 2.236 \\
\hline
\end{tabular}

Source:http://www.qardhasan.org 


\section{Conclusion}

The aim of the paper was to study and analyze whether the Islamic economic and financial system contribute and support the MDGs to fight against poverty and alleviate gender inequality. A set of sub-questioned were presented in addition to the main problematic. We tempted to analyze them in order to highlight the phenomena regarding poverty, the main causes and especially what were the various measures and strategies being carried out in order to fight against poverty in general and women's poverty in particular. Throughout this study, we attempted to focus our study and analysis on the possible contribution of Islamic economic and finance system to alleviate and fight against poverty and alleviate gender equality.

We can conclude that, despite the expansion of poverty with a large portion of the world population, the women's poverty is a worldwide phenomenon that affect more and more the feminine gender for various reasons. Indeed, women face more difficulties than men in terms of access to employment; lack of education, receives lower wages compared to their male counterparts; difficulties to access to high hierarchical levels; some societies and cultures deny women's work and even basic education ... Thus, tackling gender inequality and addressing the rights for women are closely tied to enhancing knowledge, power and confidence. Little or no schooling has a negative effect on women's personal development and the health and well-being of their families and communities. In addition, it limits income and employment opportunities as well as their ability to help in their children's education. Low levels of literacy can make it difficult for women to effectively participate in socio-economic development and political activities.

Besides a number of measures and strategies that might be used to fight against poverty, like the steps taken by the World Bank, UN, USAID, charities and NGOs; Islamic economic and finance system is considered as a major element that ought to be increasingly used in poverty alleviation policies and strategies, especially in the Muslim countries. Effectively, in addition to the traditional role of charities instruments and institutions of this system (qardhassan, zakat and waqf) and the contribution of Islamic Development Bank; a large number of poor people, especially women, can help to reduce poverty and contribute to self-esteem through Islamic microfinance. Indeed, Islamic microfinance allows the poor and/or the needy to realize their own projects (in agriculture, industry or services), increase their income, and contribute to the creation of wealth and employment.

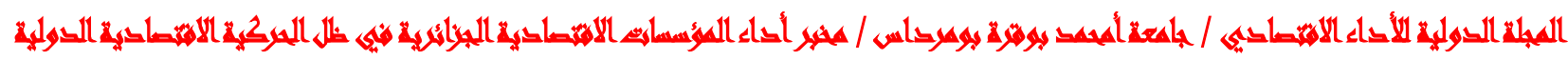
العقد الإول - موان 2018 


\section{Referrals and references}

- Ahmed Habib. (2004); "Role of zakah and awqaf in poverty alleviation"; Occasional paper No.8; Islamic Development Bank; Jeddah.

- Alkire. S \& others. (March 2013); "Multidimensional Poverty Index 2013"; OPHI (Oxford Poverty \& Human Development Initiative, ODID); Oxford University.

- Ben Abdelkader.I\& Ben Salem. A. (May 2013); "Islamic vs conventional microfinance institutions: Performance analysis in MENA coutries; International Journal of Business and Social Research (IJBSR); Vole-3; No-5.

- Ben Azouz Abdul Qadir. (2004), "jurisprudence waqf investment and financing in Islam: An Empirical Study of the algerianwaqf," the University of Algiers.

- CagatayNilufer. (May 1998); "Gender and poverty"; Working paper series No.5; Social development and poverty elimination division; United Nations Development Programme.

- Chant Sylvia. (February 2008); “The 'Feminization of poverty' and the 'Feminization' of anti-poverty programmes: Room for revision?"; Journal of Development Studies; Vol. 44, No. 2.

- Clarke Matthwe. (n.d). Does qardul-hassan enhance the impact of microfinance on clients' income and expenditure? Case studies of three Islamic charity based microfinance in Indonesia. Deakin University. Australia.

- De Navas Walt Carmen \& others; "Income, poverty, and health insurance coverage in the United States: 2010"; U.S. CENSUS Bureau; September 2011.

- FAO (Food and Agriculture Organization of the United Nations). (2011); "The stated of Food and Agriculture Report"; Rome.

- Geremek. B. (1987); «La potence ou la pitié. L'Europe et les pauvres du Moyen Age à nos jours »; Edition Gallimard ; Paris.

- Hassan. M.K. (2010); «An integrated poverty alleviation model combining zakat, awqaf and micro-finance"; Seven International Conference-The tawhidi epistemology: zakat and waqf economy; Bangi

- Islamic Development Bank. (2008); «Thirty-four years in the service of Development"; Jeddah.

- Islamic Development Bank Group. (May 2013); "39 years in the service of development"; Jeddah.

- Islamic Relief Worldwide (December 2012); "2012 annual report and financial statements"; UK.

- Lecerf Marie. (March 2016). Poverty in the European Union: the crisis and its aftermath. European Parliamentary Research Service. Belgium.

- LordeAudre. (2016). Poverty is sexist. Washington. USA.

- Mestrum. F \&Ozden. M. (June 2012); «The fight against poverty and human rights"; Critical report $\mathrm{n}^{\circ} 11$; CETIM-Europe-Third World Centre; Geneva.

- Nalara. R.B. (June 2009); « NGOs, poverty reduction and social exclusion in Uganda"; The Hague University; The Netherlands.

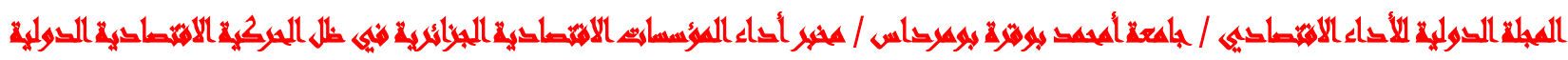
العقد الإول - موان 2018 
- RiwajantiNur Indah. (March, $7^{\text {th }}$ 2014); "Exploring the role of Islamic microfinance institution in poverty alleviation through microenterprises development: Case study of Islamic financial cooperative (BMT) in Indonesia"; Kyoto Bulletin of Islamic Area Studies.

- Shepherd. A \& others. (2014); "The chronic poverty report 2014-2015: The road to zero extreme poverty"; Overseas Development Institute; UK.

- Shirazi. N.S. (May 2014);'Integrating zakat and waqf into the poverty reduction strategy of the IDB member countries"; Islamic Economic Studies; Vol. 22, No. 1.

- Stirk Chloe. (March 2015). An act of faith: Humanitarian financing and zakat. Global Humanitarian Assistance. UK.

- Simmel. G. (1998); « Les pauvres »; Edition PUF; Paris; $\left(1^{\text {st }}\right.$ edition in 1907)

- UNDP. (1997); « Human Development Report »; Oxford University Press; New York.

- United Nations Development Programme. (November 2012); «Scaling up Islamic microfinance in Bangladesh through the private sector: Experience of Islamic Bank Bangladesh Limited (IBBL); New York-USA.

- United Nations. (2014). The millennium development goals report. New York. USA.

- USAID Iraq. (March 2013); "USAID-Tijara provincial economic growth program: February 2008-March 2013"; Final Report.

- ${ }^{1}$ http://www.nwlc.org

- 2 http://www.usaid.gov

- 3 http://www.adequations.org

- 4 http://www.un.org

- 5 http://www.adequations.org

- ${ }^{6} \mathrm{http}: / / \mathrm{www} . u n . o r g$

- 7 http://www.kantakji.org

- ${ }^{8}$ Adapted from Data compilation from internal reports (2003-2013); Ministry of Religious Affairs and Waqf; Algeria.

- ${ }^{9}$ www.marw.dz

- ${ }^{10} \mathrm{http}: / /$ www.lescahiersdelislam.fr

- ${ }^{11} \mathrm{http}: / /$ irshad.gov

- ${ }^{12} \mathrm{http}: / / \mathrm{www}$.islamic-relief.org

- ${ }^{13} \mathrm{http}: / /$ www.isdb.org

- 14 http://islamicvoice.com

- 15 www.marw.dz

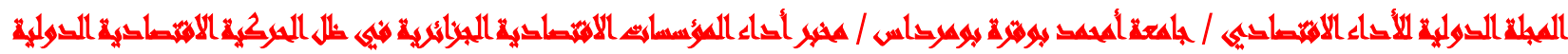
العقى الإول - موان 2018 